\author{
Kaan Gündüz \\ Carol L. Shields \\ Ilhan Günalp \\ Jerry A. Shields
}

\section{Magnetic resonance imaging of unilateral lacrimal gland lesions}

Published online: 11 March 2005

(C) Springer-Verlag 2005

The online version of the original article can be found at http:// dx.doi.org/10.1007/s00417-003-0748-Z

K. Gündüz $(\bowtie) \cdot$ I. Günalp

Oncology Service, Department of Ophthalmology,

Ankara University, Faculty of Medicine, Ankara, Turkey

e-mail: eyemd@ada.net.tr

Fax: +90-312-2291812

K. Gündüz

G.M.K. Bulvari 116/3, 06570 Maltepe, Turkey

C. L. Shields · J. A. Shields

Oncology Service, Wills Eye Hospital,

Thomas Jefferson University,

Philadelphia, Pennsylvania, USA

\section{Graefe's Arch Clin Exp Ophthalmol (2003) 241:907-913}

The entire list of References was published wrong. The correct list reads as follows:

\section{References}

1. De Potter P, Dolinskas C, Shields CL, Shields JA (1995) Tumors of the lacrimal gland. In: De Potter P, Shields JA, Shields CL (eds) MRI of the eye and orbit, JB Lippincott, Philadelphia, pp 227-235

2. De Potter P, Flanders AE, Shields JA, Shields CL, Gonzales CF, Rao VM (1994) The role of fat suppression technique and gadopentate dimeglumine in magnetic resonance imaging evaluation of intraocular tumors and simulating lesions. Arch Ophthalmol 112:340-348

3. Frohman LP, Kupersmith MJ, Lang J, Reede D, Bergeron RT, Aleksic S, Trasi S (1986) Intracranial extension and bone destruction in orbital pseudotumor. Arch Ophthalmol 104:380-384

4. Hornblass A, Friedman AH, Yagoda A (1981) Erosion of the orbital plate (frontal bone) by a benign tumor of the lacrimal gland. Ophthalmic Surg 12:737-743

5. Jakobiec FA, Yeo JH, Trokel S, Abbott GF, Anderson R (1982) Combined clinical and computed tomographic diagnosis of primary lacrimal fossa lesions. Am J Ophthalmol 94:785-807
6. Lemke AJ, Hosten N, Grote A, Felix R (1996) Differentiation of lacrimal gland tumors with high resolution computerized tomography in comparison with magnetic resonance tomography. Ophthalmologe 93:284-291

7. Mafee MF (1996) Eye and orbit. In: Som PM, Curtin HD (eds) Head and neck imaging, 3rd edn. Mosby, St. Louis, pp 1059-1128

8. Mafee MF, Edward DP, Koeller KK, Dorodi S (1999) Lacrimal gland tumors and simulating lesions. Clinicopathologic and MRI imaging features. Radiol Clin North Am 37:219-239

9. Parks SL, Glover AT (1990) Benign mixed tumors arising in the palpebral lobe of the lacrimal gland. Ophthalmology 97:526-530

10. Polito E, Galieni P, Leccisotti A (1996) Clinical and radiologic presentation of 95 orbital lymphoid tumors. Graefes Arch Clin Exp Ophthalmol 234:504509

11. Reese AB (1956) The treatment of expanding lesions of the orbit: with particular regard to those arising in the lacrimal gland. The Seventh Arthur J. Bedell Lecture. Am J Ophthalmol 41:311
12. Rose GE, Wright JE (1992) Pleomorphic adenoma of the lacrimal gland. $\mathrm{Br}$ J Ophthalmol 76:395-400

13. Shields CL, Shields JA, Eagle RC, Rathmell JP (1989) Clinicopathologic review of 142 cases of lacrimal gland lesions. Ophthalmology 96:431-435

14. Shields JA (1989) Diagnosis and management of orbital tumors. Saunders, Philadelphia, pp 259-274

15. Shields JA (1989) Diagnosis and management of orbital tumors. Saunders, Philadelphia, pp 316-340

16. Shields JA, Shields CL, Eagle RC Jr, Singh AD, Armstrong T (2001) Metastatic renal cell carcinoma to the palpebral lobe of the lacrimal gland. Ophthalmic Plast Reconstr Surg 17:191-194

17. Vangveeravong S, Katz SE, Rootman J, White V (1996) Tumors arising in the palpebral lobe of the lacrimal gland. Ophthalmology 103:1606-1612

18. Wright JE, Stewart WB, Krohel GB (1979) Clinical presentation and management of lacrimal gland tumors. Br J Ophthalmol 63:600-606 